\title{
Demersal fish assemblages and habitat characteristics on the continental shelf and upper slope of the north-western Mediterranean
}

\author{
Montserrat Demestre*, Pilar Sánchez and Pere Abelló \\ Institut de Ciéncies del Mar (CSIC), P. Joan de Borbó, s/n, 08039 Barcelona, Spain.*E-mail: montse@icm.csic.es
}

\begin{abstract}
Continental shelf and upper slope fish communities were studied along the Catalan coast based on 66 experimental bottom otter trawls. A total of 79 demersal fish species were studied by means of cluster analysis and multi-dimensional scaling (MDS) ordination for community structure. Analysis revealed the existence of five major location clusters. Similarity percentage analysis (SIMPER) was determined by comparing the dissimilarity between two groups of samples using the discriminating species. Geomorphological characteristics, bottom substratum and depth showed direct influences on species assemblages. High correlation between the biotic data samples and depth was observed. The fish species assemblages identified five main demersal fish associations which corresponded with the five location clusters and with five benthic sediments (mud of the upper slope, sand and gravel, mud of the shelf, muddy-sand and sand with rocky outcrops).
\end{abstract}

\section{INTRODUCTION}

The Mediterranean coasts support important demersal fisheries, with the Catalan coast being a typical example. It is approximately $550 \mathrm{~km}$ long with 28 ports, 18 of which have daily fishing activity (Martín, 1991; Lleonart, 1993). Surveys to study the demersal animal communities on the continental shelf and upper slope off the Catalan coast have been focused on faunistic studies of decapod crustaceans (Abelló et al., 1988; Cartes \& Sardà, 1993), and studies related to fish communities have been conducted chiefly on bathyal and slope bottoms (Stefanescu et al., 1993, 1994). Studies performed on the continental shelf and upper slope in other areas of the Mediterranean are source material (e.g. D’Onghia et al., 1998; Moranta et al., 1998; Ungaro et al., 1998; Vassilopoulou et al., 1998).

The present study aims to analyse the structure and seasonality of the fish communities from the shelf and upper slope off the Catalan coast. The objective was to describe its faunistic composition and to establish the main faunistic assemblages of fish species based on interspecific associations according to bottom types and depth.

\section{MATERIALS AND METHODS}

Study area: topography and sediment structure

The Catalan coast (Figure 1) can be divided into three different topographic units (Demestre, 1986). The northern zone consists mainly of a rocky coast, with a predominance of sand and sandy-muddy bottoms. The distribution of superficial sediments on the continental shelf gradually changes from sand and gravel associated with rocky outcrops, carbonated sands with a gravel matrix, muddy carbonated sands, to the sandy-mud and finally the mud and clay of the outer part of the shelf and continental slope (Medialdea et al., 1986; Ercilla et al.,
1995). The shelf is narrow, and can reach depths of $800 \mathrm{~m}$ on the slope at only 6 or $7 \mathrm{~km}$ from the coast, owing to the presence of submarine canyons. The southern zone has very different characteristics. Its shelf is very wide (at some points over $65 \mathrm{~km}$ ), with a predominance of muddysand and mud bottoms inherent to the continental shelf. It is an area of influence for continental waters from the River Ebro. Six types of sediments have been defined in this area ranging from those with a minimum sand content, clay-muddy sediments, to those that have more than $50 \%$ sand, together with the sandy sediments with a high gravel content. Mud and clay with low percentages of sand are the predominant sediment, occupying a large part of the shelf. In the sediments from more coastal area, sand predominates over mud (Medialdea et al., 1986; Guillén \& Palanques, 1997). In the central intermediate zone of the Catalan coast the shelf is not very wide, with some underwater canyons. The bottom is generally muddy-sand, as well as sand next to small formations of rocky barriers close to the coastal line. In this area the carbonated sedimentary facies are frequent. They are rich in calcareous algae, molluscs, echinoderms, and also sea grass meadows which contain an important fraction of epiphytic fauna (Guillén \& Palanques, 1997).

\section{Methodology}

Sampling was performed quarterly during 1991 using otter bottom trawls along the Catalan coast (winter $=17$ hauls, spring $=12$, summer $=14$, autumn $=23$, Table 1 ). The areas exploited by three representative ports were chosen: Blanes in the north, Vilanova i la Geltrú in the central zone and Sant Carles de la Ràpita in the southern zone (Figure 1). A commercial fishing trawl with a distance between wings of approximately $30 \mathrm{~m}$ was used, with a stretched mesh size of $36 \mathrm{~mm}$. A total of 66 experimental hauls were conducted out in a depth stratified sampling 


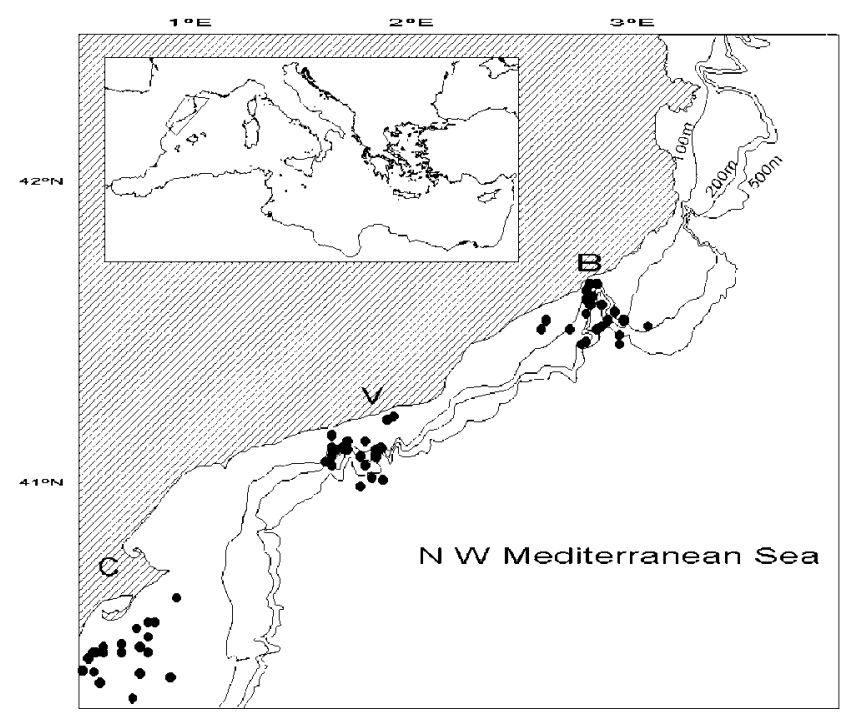

Figure 1. Map of the Catalan coast illustrating the position of the trawl samples and location of the three selected ports. B, Blanes; V, Vilanova; C, Sant Carles. 100 m, 200 m and $500 \mathrm{~m}$ isobaths are shown. grid (in the northern area 21, 23 on the central and 22 in the southern; Table 1). Tows had a duration of 60-120 min depending on the bottom characteristics, and were standardized to $60 \mathrm{~min}$ [number individuals per hour hauling (ind $\left.\left.\mathrm{h}^{-1}\right)\right]$, for subsequent numerical and comparative processing. The mean depth of the hauls ranged between 22 and $548 \mathrm{~m}$ (north $=37-522 \mathrm{~m}$, central $=29-548 \mathrm{~m}$, south $=22-74 \mathrm{~m}$; Table 1$)$. All hauls were conducted during daylight hours.

The catch of each sample was sorted, and all fish collected were identified to species level, counted and weighed. Analysis of data abundance was carried out by using the PRIMER (Plymouth Routines in Multivariate Ecological Research) package (Clarke \& Warwick, 1994). Cluster analysis was applied to the species-hauls matrix using multidimensional scaling (MDS) techniques, and the double square root transformation. The percentage haul similarity was calculated by means of the Bray-Curtis index; a group average fusion strategy, with UPGMA (unweighted pair-group method using arithmetric averages) being applied to link similar samples into clusters. Similarities between samples were displayed on ordination plots following the application of

Table 1. Summary of sampling data.

\begin{tabular}{|c|c|c|c|c|c|c|c|c|c|}
\hline Num & Date & Depth (m) & Area & Bottom & Num & Date & Depth (m) & Area & Bottom \\
\hline 1 & $06 / 03 / 91$ & 154.8 & V & M & 34 & $10 / 07 / 91$ & 21.6 & $\mathrm{C}$ & $\mathrm{S}$ \\
\hline 2 & $07 / 03 / 91$ & 189.0 & B & M & 35 & $18 / 09 / 91$ & 57.6 & $\mathrm{~V}$ & $\mathrm{R}$ \\
\hline 3 & $27 / 03 / 91$ & 41.4 & $\mathrm{C}$ & $\mathrm{X}$ & 36 & $05 / 09 / 91$ & 423.0 & B & $\mathrm{M}$ \\
\hline 4 & $06 / 03 / 91$ & 175.5 & V & M & 37 & $02 / 10 / 91$ & 24.3 & $\mathrm{C}$ & $\mathrm{S}$ \\
\hline 5 & $07 / 03 / 91$ & 333.0 & B & M & 38 & $18 / 09 / 91$ & 212.4 & $\mathrm{~V}$ & $\mathrm{M}$ \\
\hline 6 & $27 / 03 / 91$ & 45.9 & $\mathrm{G}$ & $\mathrm{X}$ & 39 & $05 / 09 / 91$ & 180.0 & B & $\mathrm{M}$ \\
\hline 7 & $06 / 03 / 91$ & 59.4 & $\mathrm{~V}$ & $\mathrm{X}$ & 40 & $02 / 10 / 91$ & 42.3 & $\mathrm{C}$ & $\mathrm{X}$ \\
\hline 8 & $07 / 03 / 91$ & 436.5 & B & $\mathrm{M}$ & 41 & $18 / 09 / 91$ & 180.0 & V & M \\
\hline 9 & $27 / 03 / 91$ & 27.0 & $\mathrm{G}$ & $\mathrm{S}$ & 42 & $05 / 09 / 91$ & 110.7 & B & $\mathrm{T}$ \\
\hline 10 & $06 / 03 / 91$ & 48.6 & V & $\mathrm{R}$ & 43 & $02 / 10 / 91$ & 47.7 & $\mathrm{C}$ & $\mathrm{X}$ \\
\hline 11 & $07 / 03 / 91$ & 128.7 & B & $\mathrm{X}$ & 44 & $18 / 09 / 91$ & 36.9 & V & $\mathrm{R}$ \\
\hline 12 & $27 / 03 / 91$ & 25.2 & $\mathrm{C}$ & $\mathrm{S}$ & 45 & $05 / 09 / 91$ & 100.8 & B & $\mathrm{X}$ \\
\hline 13 & $06 / 03 / 91$ & 63.9 & $\mathrm{~V}$ & $\mathrm{R}$ & 46 & $02 / 10 / 91$ & 21.6 & $\mathrm{C}$ & $\mathrm{S}$ \\
\hline 14 & $07 / 03 / 91$ & 127.8 & B & $\mathrm{X}$ & 47 & $18 / 09 / 91$ & 31.5 & $\mathrm{~V}$ & $\mathrm{~S}$ \\
\hline 15 & $27 / 03 / 91$ & 45.9 & $\mathrm{C}$ & $\mathrm{X}$ & 48 & $02 / 10 / 91$ & 36.0 & $\mathrm{C}$ & $\mathrm{S}$ \\
\hline 16 & $06 / 03 / 91$ & 30.6 & V & $\mathrm{R}$ & 49 & $20 / 10 / 91$ & 57.6 & B & $\mathrm{R}$ \\
\hline 17 & $27 / 03 / 91$ & 47.7 & $\mathrm{G}$ & $\mathrm{X}$ & 50 & $20 / 10 / 91$ & 247.5 & B & $\mathrm{M}$ \\
\hline 18 & $29 / 05 / 91$ & 193.5 & B & M & 51 & $20 / 10 / 91$ & 351.0 & B & $\mathrm{M}$ \\
\hline 19 & $29 / 05 / 91$ & 270.9 & B & $\mathrm{M}$ & 52 & $20 / 10 / 91$ & 109.8 & B & $\mathrm{X}$ \\
\hline 20 & $29 / 05 / 91$ & 522.0 & B & M & 53 & $20 / 10 / 91$ & 36.9 & B & $\mathrm{R}$ \\
\hline 21 & $29 / 05 / 91$ & 104.4 & B & $\mathrm{T}$ & 54 & $20 / 10 / 91$ & 42.3 & B & $\mathrm{R}$ \\
\hline 22 & $29 / 05 / 91$ & 95.4 & B & $\mathrm{T}$ & 55 & $13 / 11 / 91$ & 196.2 & $\mathrm{~V}$ & M \\
\hline 23 & $29 / 05 / 91$ & 98.1 & B & $\mathrm{T}$ & 56 & $27 / 11 / 91$ & 27.0 & $\mathrm{C}$ & $\mathrm{S}$ \\
\hline 24 & $05 / 06 / 91$ & 48.6 & $\mathrm{~V}$ & $\mathrm{X}$ & 57 & $13 / 11 / 91$ & 548.1 & $\mathrm{~V}$ & M \\
\hline 25 & $05 / 06 / 91$ & 54.0 & $\mathrm{~V}$ & $\mathrm{X}$ & 58 & $27 / 11 / 91$ & 30.6 & $\mathrm{C}$ & $\mathrm{S}$ \\
\hline 26 & $05 / 06 / 91$ & 65.7 & V & $\mathrm{R}$ & 59 & $13 / 11 / 91$ & 465.3 & $\mathrm{~V}$ & $\mathrm{M}$ \\
\hline 27 & $05 / 06 / 91$ & 65.7 & V & $\mathrm{R}$ & 60 & $27 / 11 / 91$ & 27.9 & $\mathrm{C}$ & $\mathrm{S}$ \\
\hline 28 & $05 / 06 / 91$ & 57.6 & $\mathrm{~V}$ & $\mathrm{R}$ & 61 & $13 / 11 / 91$ & 32.4 & $\mathrm{~V}$ & $\mathrm{~S}$ \\
\hline 29 & 05/06/91 & 57.6 & $\mathrm{~V}$ & $\mathrm{R}$ & 62 & $27 / 11 / 91$ & 22.5 & $\mathrm{C}$ & $\mathrm{S}$ \\
\hline 30 & $10 / 07 / 91$ & 73.8 & $\mathrm{C}$ & $\mathrm{X}$ & 63 & $13 / 11 / 91$ & 38.0 & $\mathrm{~V}$ & $\mathrm{~S}$ \\
\hline 31 & $10 / 07 / 91$ & 72.0 & $\mathrm{G}$ & $\mathrm{X}$ & 64 & $27 / 11 / 91$ & 22.5 & $\mathrm{C}$ & $\mathrm{S}$ \\
\hline 32 & $10 / 07 / 91$ & 45.9 & $\mathrm{C}$ & $\mathrm{X}$ & 65 & $13 / 11 / 91$ & 28.8 & $\mathrm{~V}$ & $\mathrm{~S}$ \\
\hline 33 & $10 / 07 / 91$ & 21.6 & $\mathrm{C}$ & $\mathrm{S}$ & 66 & $27 / 11 / 91$ & 23.4 & $\mathrm{C}$ & $\mathrm{S}$ \\
\hline
\end{tabular}

Num, number of the haul; Area, selected ports-B, Blanes in the north; V, Lilanova i la Geltrú in the centre; C, Sant Carles de la Ràpita in the south; Bottom, bottom type-M, muddy bottoms on the upper slope; T, sandy and gravel bottoms; X, muddy mud-clay bottoms on the shelf; S, muddy-sand bottoms; R, muddy-carbonated sand bottoms associated with rocky outcrops. 
MDS. To establish which were the main species that contributed to the average Bray-Curtis dissimilarity between two groups of samples, the SIMPER (similarity percentage analysis) routine was used (Clarke, 1993). The ten dominant species are presented in the results. Abundance and biomass were compared for the species of the groups obtained from cluster analysis and MDS.

In the case of species, the relationship between distribution and bottom types has been studied by means of MDS ordination. This relationship has been based on the type of sediment from each haul (Ercilla et al., 1995; Guillén \& Palanques, 1997), and the characteristic habitats of each one of them (Pérès \& Picard, 1964; Demestre, 1986). So each species has been assigned to a type of bottom based on the most frequent type in which it was present (see codes in Table 1).

\section{RESULTS}

\section{Sample associations}

A total of 124 fish species were captured in the present study, but only those appearing in over $3 \%$ of the samples were considered for further analysis (Table 2).

Cluster analysis of the samples (Figure 2) showed the occurrence of two main assemblages: (1) samples from the shelf edge and upper slope; and (2) those from more coastal areas (shallow waters and intermediate shelf). Within the shelf edge and upper slope group (1), two subgroups of samples were identified: (A) samples from the shelf edge with a mean \pm SD depth of $109.5 \pm 12.7 \mathrm{~m}$; and (B) samples from the upper slope, with a mean depth of $298.7 \pm 133.8 \mathrm{~m}$. The coastal group (2) showed three main assemblages. The first division, (C) was formed by a group of samples from the northern area with a mean depth of $45.6 \pm 10.7 \mathrm{~m}$; a second division contained two groups of samples (D and E) from the central and southern areas: group D with a mean depth of 49.2 $\pm 13.0 \mathrm{~m}$, and group $\mathrm{E}$, the most coastal, with a mean depth of $35.8 \pm 15.5 \mathrm{~m}$. The result of MDS analysis (Figure 3) confirmed the clear separation of the five groups of samples, with the separation of groups A and B from the others being especially evident. The analyses of relationship between depth and sample associations showed a high weighted Spearman correlation value, 0.747 .

The results of the SIMPER (Table 3) showed the average dissimilarity between the five main location clusters. These groups appeared to be very well defined since the separation between them was very high. So the shallow water group (E) and the upper slope group (B) showed the highest average dissimilarity value, 92.79. The most similar were the shallow water group (E) and the intermediate shelf group (D) with an average dissimilarity value of 62.9. A different community structure strongly linked to seasonality appears to be the key factor differentiating the two shallow shelf assemblages, D and E. Hake, with its peak recruitment in spring (average abundance $=815.42$ ind $\mathrm{h}^{-1}$; Table 3) in group $\mathrm{D}$, vs gobiids and red mullet, with their peak recruitment in late summer and autumn in group E (Lesuerigobius friesii=116.69 ind $\mathrm{h}^{-1}$; Deltentosteus quadrimaculatus $=58.74 \mathrm{ind}^{-1}$ and Mullus barbatus $=125.59$ ind $\mathrm{h}^{-1}$; Table 3), are the most

Table 2. Total species caught off the Catalan coast. Code: Species identifying number used in the MDS ordination.

\begin{tabular}{|c|c|c|c|c|c|}
\hline Species & Code & Species & Code & Species & Code \\
\hline Alosa fallax & 1 & Gadiculus argenteus & 28 & Raja asterias & 55 \\
\hline Argentina sphyraena & 2 & Gaidropsarus mediterraneus & 29 & Sardina pilchardus & 56 \\
\hline Arnoglossus laterna & 3 & Glossanodon leioglossus & 30 & Scorpaena loppei & 57 \\
\hline Arnoglossus ruepelli & 4 & Gobius niger & 31 & S. notata & 58 \\
\hline A. thori & 5 & Helicolemus dactylopterus & 32 & Scyliorhinus canicula & 59 \\
\hline Aspitriglacuculus & 6 & Hymenocephalus italicus & 33 & Seriola dumerili & 60 \\
\hline A. obscura & 7 & Lampanyctus crocodilus & 34 & Serranus cabrilla & 61 \\
\hline Blennius ocellaris & 8 & Lepidopus caudatus & 35 & S. hepatus & 62 \\
\hline Boops boops & 9 & Lepidorhombus boscii & 36 & Solea vulgaris & 63 \\
\hline Bothus podas & 10 & Lepidotrigla cavillone & 37 & Sphyraena sphyraena & 64 \\
\hline Callionymus maculatus & 11 & Lesueurigobius friesii & 38 & Spicara spp. & 65 \\
\hline C.reticulatus & 12 & L. suerii & 39 & Stomias boa & 66 \\
\hline Capros aper & 13 & Lophius boudegassa & 40 & Symphurus ligulatus & 67 \\
\hline Cepola rubescens & 14 & L.piscatorius & 41 & S. nigrescens & 68 \\
\hline Chlorophthalmus agasizii & 15 & Merluccius merluccius & 42 & Synchiropus phaeton & 69 \\
\hline Citharus linguatula & 16 & Microchirus variegatus & 43 & Torpedo marmorata & 70 \\
\hline Coelorhinchus coelorhinchus & 17 & Micromesisteus poutassou & 44 & Trachinus draco & 71 \\
\hline Conger conger & 18 & Mullus barbatus & 45 & Trachurus spp. & 72 \\
\hline Crystallogobius linearis & 19 & M. surmuletus & 46 & Trachyrhynchus trachyrhynchus & 73 \\
\hline Deltentosteus quadrimaculatus & 20 & Notoscopelus elongatus & 47 & Trigla lucerna & 74 \\
\hline Diplodus annularis & 21 & Ophidion barbatum & 48 & T. lyra & 75 \\
\hline D. sargus & 22 & Pagellus acarne & 49 & Trigloporus lastoviza & 76 \\
\hline D. vulgaris & 23 & P.bogaraveo & 50 & Trisopterus minutus & 77 \\
\hline Echelus myrus & 24 & P. erythrinus & 51 & Uranoscopus scaber & 78 \\
\hline Engraulis encrasicolus & 25 & Phycis blennoides & 52 & Zeusfaber & 79 \\
\hline Etmopterus spinax & 26 & P.phycis & 53 & & \\
\hline Eutrigla gurnardus & 27 & Pomatomus saltatrix & 54 & & \\
\hline
\end{tabular}




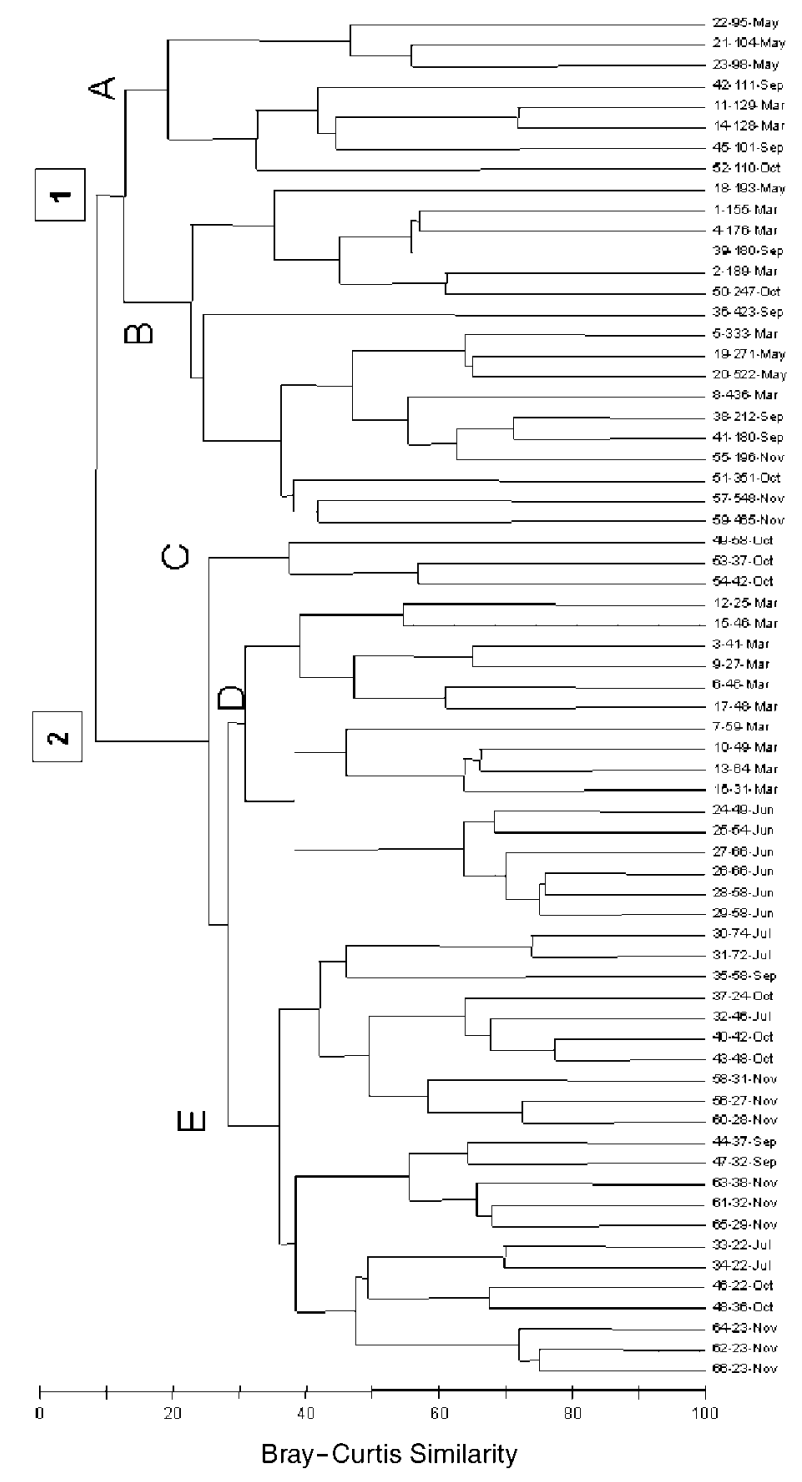

Figure 2. Dendrogram of trawl samples similarity based in Bray-Curtis distance and UPGMA, showing the major clusters: 1, shelf edge/upper slope (A and B clusters); 2, intermediate shelf/ shallow waters (C, D and E). Sample number, mean depth $(\mathrm{m})$ and month are shown for each sample.

important controlling species of these assemblages. The species which appeared as excellent discriminators between groups are marked with an asterisk (*) in Table 3. Thus, Micromesistius poutassou and Gadiculus argenteus appear as characteristic species for group B; Lophius piscatorius and Arnoglossus thori for group A; Trachinus draco for group C; Cepola rubescens from group D and Deltentosteus quadrimaculatus from group E. Some species appeared in all the groups, although with very different abundances. This was the case for Arnoglossus laterna and Merluccius merluccius, since both had a wide bathymetric distribution range.

\section{Species assemblages}

The classification and ordination of the 79 species, as presented in the MDS diagram (Figure 4), showed five main associations. The five species associations identified

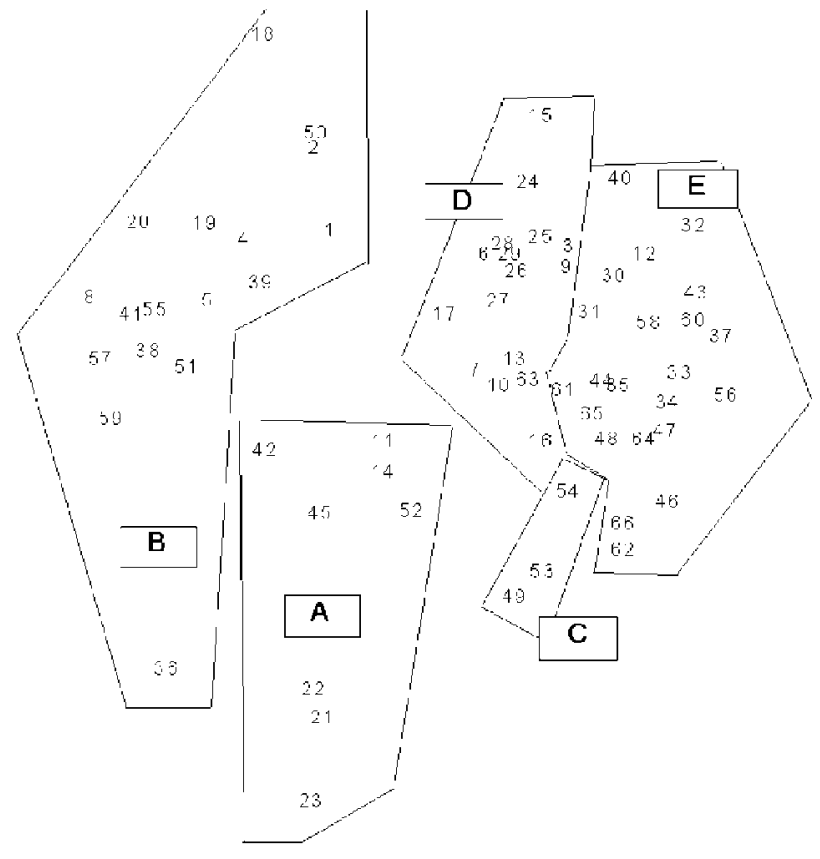

Figure 3. Multidimensional scaling diagram of trawl samples indicating the groupings obtained from the cluster analysis (Figure 2) $($ stress $=0.18)$.

by means of the classification analysis and ordination of the species had a good separation level (stress=0.25), and they also basically coincided with the five major location clusters.

The $\mathrm{M}$ group of species was associated with an average depth of $298.7 \mathrm{~m}$. The most characteristic species in this group were Micromesistius poutassou, Gadiculus argenteus, Lophius budegassa, Coelorhynchus coelorhynchus, Lepidopus caudatus and Phycis blennoides. This group of species was strongly associated with the B cluster of samples. The association identified as $\mathrm{T}$ was caught at a mean depth of $102.2 \mathrm{~m}$. The most representative species were Lophius piscatorius, Arnoglossus thori, Arnoglossus rueppelli, Microchirus variegatus and Eutrigla gurnardus. These species were gathered in part of A cluster of the samples. The association $\mathrm{X}$ represented the species distributed along the whole coast studied, being found at a greater or shallower depth depending on the configuration of the coast. Thus, in the northern area this community was found at a mean depth of $116.78 \mathrm{~m}$, and was identified with part of the A cluster of the samples. On the remainder of the coast (wide shelf) this community appeared at a mean depth of $52.0 \mathrm{~m}$. This group of species from the southern middle shelf was part of the D and E groups of samples. The most characteristic species of this community were Cepola rubescens, Solea vulgaris, Lepidorhombus boscii, Conger conger, Merluccius merluccius and Trisopterus minutus capelanus. Another identified assemblage $(\mathrm{S})$ was that of species that lived on bottoms on the shallow shelf and were also found along the whole coast at a mean depth of $27.2 \mathrm{~m}$. They were identified with part of groups D and $\mathrm{E}$ in the cluster of samples. The most characteristic species of this community were Mullus barbatus, Deltentosteus quadrimaculatus, Pagellus acarne, Trigla lucerna, Lesueurigobius friesii, Citharus linguatula, Sardina pilchardus and Engraulis encrasicolus. Finally, the association R 

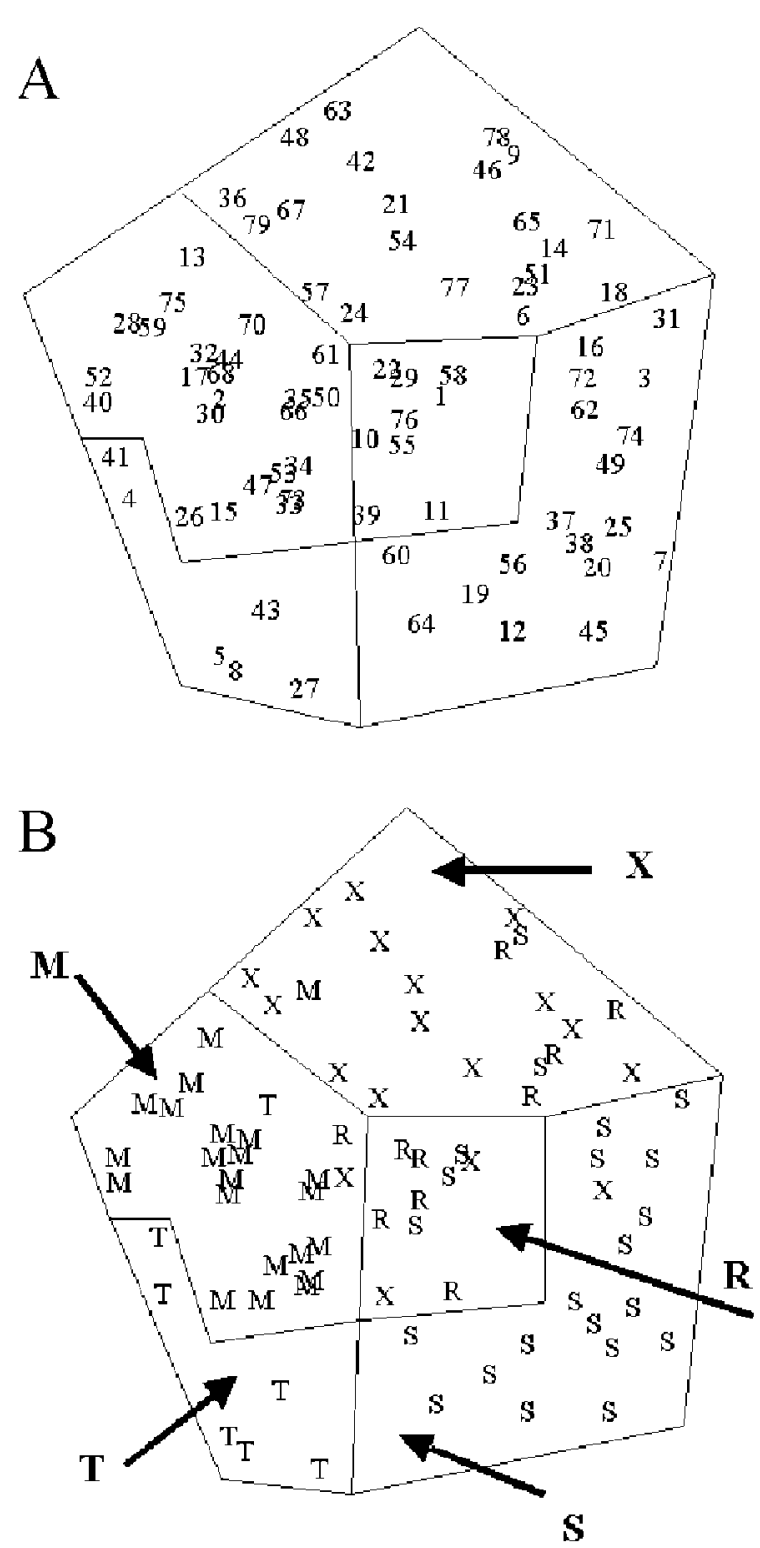

Figure 4. Multidimensional scaling diagram of the species: (A) species codes (see Table 2); (B) type of bottom for each species (codes in Table 1). The groups shown correspond to those obtained from the species dendrogram (not represented). Each species has been assigned to a type of bottom based on the most frequent type of bottom in which it was present $($ stress $=0.27)$.

contained species characteristic of bottoms with a very direct influence from the sea-grass meadows, especially Posidonia oceanica. Typical species from these bottoms were Trachinus draco, Mullus surmuletus, Pagellus erythrinus, Aspitrigla cuculus and Serranus cabrilla. These habitats can be found at variable depths depending on the coastal area in which they are found. Part of D and $\mathrm{E}$ groups on samples represented these species associations, with a mean depth of $53.8 \mathrm{~m}$, and also by group $\mathrm{C}$ with a mean depth of $45.6 \mathrm{~m}$.

\section{DISCUSSION}

Depth is usually considered the main association factor between species, even in upwelling areas where the concentration of dissolved oxygen is one of the delimiting factors in the distribution of the species (Mas Riera et al., 1990; Bianchi, 1992). In the studied area of the Mediterranean, where the presence of anoxic areas does not occur, depth is the main factor affecting the associations of demersal fish. Additionally, the temperature of the water as a direct consequence of seasonality has a certain effect on the demersal fauna, and more specifically on its differential patterns of distribution during the life cycle of some species. This is reflected in the appearance of the juveniles or of reproductive adults of certain species on a particular bottom type and at a specific depth, such as in the hake, the red and stripped mullet or the different sparidae species (Aldebert et al., 1998; Demestre \& Sánchez, 1998). There are different fractions of the same species, juveniles and adults, which are distributed in a different way. The seasonality of the studied area has been shown in various studies (Masó \& Duarte, 1989; Sabatés, 1990) on the sequential nature in the appearance of planktonic organisms that constitute an important energy source.

The different types of bottom sediments, are also an important delimiting factor for the association of fish species in different communities. The clear differences between very defined habitats, such as those of mud bottoms on the slope and the sandy, much more coastal areas, support well-differentiated fish communities. In the Mediterranean, species such as Mullus surmuletus, Pagellus erythrinus, Callyonimus maculatus, Diplodus vulgaris and $D$. sargus clearly require coastal habitats of hard substratum ( $\mathrm{S}$ and $\mathrm{R}$ ), characteristic of slightly muddy carbonated sand bottoms generally related with rocky outcrops, with a carbonate component higher than 55\%, sand $(65 \%)$ and Posidonia (Demestre, 1986; Medialdea et al., 1986; Ercilla et al., 1995; Garcia-Rubies \& Macpherson, 1995). In these habitats, temperature shows the characteristic seasonal variations (around $3^{\circ} \mathrm{C}$ ) around mean temperature of $13.9^{\circ} \mathrm{C}$ (Font et al., 1988; EUROMODEL Group, 1995). In a parallel way, species such as Micromesistius poutassou, Etmopterus spinax, Trachyrhynchus trachyrhynchus, Stomias boa, Lophius budegassa and Phycis blennoides have been associated with muddy bottom habitats $(\mathrm{M})$ typical of the upper slope and shelf edge (Maurin, 1962; Stefanescu et al., 1994; Moranta et al., 1998), with soft clay-muddy sediments with a low percentage of sand $(<5 \%)$ (Guillén \& Palanques, 1997). The environmental and hydrographic conditions on these bottoms are very stable throughout the year, with mean temperature of $13.1 \pm 0.2^{\circ} \mathrm{C}$ (EUROMODEL Group, 1995). It is noticeable that the species groupings were not clearly divided into one community type for each habitat. The great mobility of many of these species meant that there could be possible visitors from other habitats. A clear example of this behaviour are Serranus cabrilla and Pagellus erythrinus, species inhabiting mainly rocky shallow waters $(\mathrm{R})$ which can be occasionally found at mud and muddy-sand bottoms ( $\mathrm{M}$ and $\mathrm{X}$ ) down to around $100 \mathrm{~m}$ depth.

Marine epibenthic species are closely associated with specific substrata or community types (Kaiser et al., 1998; Thrush et al., 1995; Jennings \& Kaiser, 1998). The results presented in this study clearly show that one of the key factors in the association of demersal and benthic fish 
species on the shelf and upper slope is the bottom type, which are clearly differentiated and identified by the composition of their different sediment facies. Obviously, this is all under the influence of depth, which is in turn a limiting factor of the presence of the different species and habitats in the studied area of the Mediterranean. We have detected that some species occur in a number of distinct assemblages across a gradient of habitats, e.g. from sand through gravel substrate whereas others only occur in very specific habitats. However, the perturbation of the structured bottom grounds by the fishery could modify the community structure and the pattern of some species, especially the scavengers due to a source of food supply (Demestre et al., 2000; Jennings et al., 1999; Ramsay et al., 1998). Those species that are able to live in different habitats and present a higher adaptability are expected to be more resilient to the effect of habitat disturbance. Such information will allow us to understand better the dynamics of the communities and populations of fish from the shelf and slope and their relationships with topographic and sediment structure of the habitats and physical environmental factors.

This study was funded by the Generalitat of Catalunya. We would like to thank the following colleagues for their participation on the project: Mr M. Marhuenda, Dr P. Martín, Ms B. Molí and Dr L. Recasens. We also thank Dr J. Guillen and Dr G. Ercilla for providing the information about sediment structure and the Oceanography Team of ICM-CSIC for information on physical parameters. We are grateful to the Fishermen Associations of Blanes, Vilanova and Sant Carles de la Ràpita ports and to the skippers of the trawl vessels used for the sampling.

\section{REFERENGES}

Abelló, P., Valladares, F.J. \& Castellón, A., 1988. Analysis of the structure of decapod crustacean assemblages off the Catalan coast (north-west Mediterranean). Marine Biology, 98, 39-49.

Aldebert, Y., Sánchez, P. \& Demestre, M., 1998. Scales of temporal variability of groundfish landings in north-western Mediterranean. Rapports et Procès-verbaux des Réunions. Commission Internationale pour l'Exploration Scientifique de la Mer Méditerranée, 35, 364-365.

Bianchi, G., 1992. Demersal assemblages of the continental shelf and upper slope of Angola. Marine Ecology Progress Series, 81, $101-120$.

Cartes, J.E. \& Sardà, F., 1993. Zonation of deep-sea decapod fauna in the Catalan Sea (western Mediterranean). Marine Ecology Progress Series, 94, 27-34.

Clarke, K.R., 1993. Non-parametric multivariate analyses of changes in community structure. Australian Fournal of Ecology, 18, 117-143.

Clarke, K.R. \& Warwick, R.M., 1994. Change in marine communities: an approach to statistical analysis and interpretation. Plymouth: Natural Environment Research Council.

Demestre, M., 1986. Les diferents comunitats naturals de la Mediterrània. In L'Oceanografia. II. Recursos pesquers de la mar catalana. Quaderns d'Ecologia Aplicada, vol. 9 (ed. J. Lleonart), pp. 9-41. Barcelona: Diputación de Barcelona.

Demestre, M. \& Sánchez, P., 1998.. Spatio-temporal distribution of the european hake Merluccius merluccius off Catalan coast (northwestern Mediterranean). Rapports et Procès-verbaux des Réunions. Commission Internationale pour l'Exploration Scientifique de la Mer Méditerranée, 35, 420-421.
Demestre, M., Sánchez, P. \& Kaiser, M.J., 2000. The behavioural response of benthic scavengers to otter-trawling disturbance in the Mediterranean. In Effects of fishing on nontarget species and habitats (ed. M.J. Kaiser and S.J. de Groot), pp. 121-129. Oxford: Blackwell Science.

D’Onghia, G., Tursi, A., Moiorano, P., Matarrese, A. \& Panza, M., 1998. Demersal fish assemblages fromm the bathyal grounds in the Ionian Sea (middle-eastern Mediterranean). Italian Fournal of Zoology, 65, 287-292.

Ercilla, G., Díaz, J.I., Alonso, B. \& Farrán, M., 1995. Late Pleistocene-Holocene sedimentary evolution of the northern Catalonia continental shelf (northwestern Mediterranean Sea). Continental Shelf Research, 15, 1435-1451.

EUROMODEL Group, 1995. Progress from 1989 to 1992 in understanding the circulation of the western Mediterranean Sea. Oceanologica Acta, 18, 255-271.

Font, J., Salat, J. \& Julià, A., 1988. Permanent features of the circulation in the Catalan Sea. Oceanologica Acta, 9, 51-57.

Garcia-Rubies, A. \& Macpherson, E., 1995. Substrate use and temporal pattern of recruitment in juvenile fishes of the Mediterranean littoral. Marine Biology, 124, 35-42.

Guillén, J. \& Palanques, A., 1997. A shoreface zonation in the Ebro Delta based on grain size distribution. Fournal of Coastal Research, 13, 867-878.

Jenning, S., Greenstreet, S.P.R. \& Reynolds, J.D., 1999. Structural changes in an exploited fish community: a consequence of different fishing effects on species with contrasting life histories. Fournal of Animal Ecology, 68, 617-627.

Jenning, S. \& Kaiser, M.J., 1998. The effects of fishing on marine ecosystems. Advances in Marine Biology, 34, 201-352.

Kaiser, M.J., Armstrong, P.J., Dare, P.J. \& Flatt, R.P., 1998. Benthic communities associated with a heavily fished scallop ground in the English Channel. Fournal of the Marine Biological Association of the United Kingdom, 78, 1045-1059.

Lleonart, J., ed., 1993. Northwestern Mediterranean fisheries. Scientia Marina, 57, 271.

Martín, P., 1991. La pesca en Cataluña y Valencia (NO Mediterráneo): análisis de las series históricas de captura y esfuerzo. Informes Tecnicos de Scientia Marina, 162, 43.

Masó, M. \& Duarte, C., 1989. The spatial and temporal structure of hydrographic and phytoplankton biomass heterogeneity along the Catalan coast. Fournal of Marine Research, 47, 813-827.

Mas Riera, J., Lombarte, A., Gordoa, A. \& Macpherson, E., 1990. Influence of the Benguela upwelling on the structure of the demersal fish populations off Namibia. Marine Biology, 104, 175-182.

Maurin, G., 1962. Étude des fonds chalutables de la Méditerranée occidentale (Écologie et Pêche). Résultats des campagnes des navieres océanographiques 'PresidentThéodore-Tissier' 1957 à 1960 et 'Thalassa' 1960 à 1961. Revues des Travaux de l'Institut des Pêches Maritimes. Paris, 26, 163-218.

Medialdea, J. et al., 1986. Mapa geológico de la plataforma continental española y zonas adjacentes, 1:200000. Memoria y Hojas $\mathcal{N}^{\underline{0}} 41$ y 42, Tortosa-Tarragona. Madrid: Servicio de Publicaciones del Ministerio de Industria y Energia, Madrid.

Moranta, J., Stefanescu, C., Massutí, E., Morales-Nin, B. \& Lloris, D., 1998. Fish community structure and depth-related trends on the continental slope of the Balearic Islands (Algerian Basin, western Mediterranean). Marine Ecology Progress Series, 171, 247-259.

Pérès, J.M. \& Picard, J., 1964. Nouveau manuel de bionomie benthique de la Mer Méditerranée. Recueil des Travaux de la Station Marine d'Endoume, 31, 1-137.

Ramsay, K., Kaiser, M.J. \& Hughes, R.N., 1998. Responses of benthic scavengers to fishing disturbance by towed gears in different habitats. Fournal of Experimental Marine Biology and Ecology, 224, 73-89. 
Sabatés, A., 1990. Distribution pattern of larval fish populations in the northwestern Mediterranean. Marine Ecology Progress Series, 59, 75-82.

Stefanescu, C., Lloris, D. \& Rucabado, J., 1993. Deep sea fish assemblages in the Catalan Sea (western Mediterranean) below a depth of $1000 \mathrm{~m}$. Deep-Sea Research, 40, 695-707.

Stefanescu, C., Morales-Nin, B. \& Massutí, E., 1994. Fish assemblages on the slope in the Catalan Sea (western Mediterranean): influence of a submarine canyon. Fournal of the Marine Biological Association of the United Kingdom, 74, 499-512.

Thrush, S.F., Hewitt, J.E., Cumming, V.J. \& Dayton, P.K., 1995. The impact of habitat disturbance by scallop dredging on marine benthic communities: what can be predicted from the results of experiments? Marine Ecology Progress Series, 129, $141-150$.

Ungaro, N., Marano, G., Marsan, R. \& Osmani, K., 1998. Demersal fish assemblage biodiversity, as an index of fishery resources explotation. Italian fournal of Zoology, 65, 511-516.

Vassilopoulou, V., Papaconstantinou, C. \& Bekas, P., 1998. Demersal fish community patterns in two areas of the Aegean Sea Greece. Italian Fournal of Zoology, 65, 293-298.

Submitted 13 March 2000. Accepted 11 May 2000.

Appendix 1. Between-group discrimination species. Species contribution to the average abundance (Av. ab.) dissimilarity between samples grouped as determined by SIMPER analyses; $R:(A v . t e / s d)$.

A. Shelf edge A vs upper slope B.

Average dissimilarity $=85.29$

Species

Av. ab. A Av. ab. B

$\mathrm{R}$

Micromesistius poutassou

Gadiculus argenteus

Arnoglossus thori

Phycis blennoides

Lepidopus caudatus

Merluccius merluccius

Helicolenus dactylopterus

Lepidorhombus boscii

Lophius piscatorius

Capros aper

$\begin{array}{cc}0 & 179.22 \\ 0 & 87.78 \\ 12.89 & 0 \\ 0 & 21.88 \\ 0 & 137.88 \\ 10.38 & 128.02 \\ 0 & 79.84 \\ 0.13 & 12.04 \\ 4.53 & 1.69 \\ 1.25 & 20.42\end{array}$

$* 2.23$

$* 1.85$

1.46

$* 1.68$

1.17

$* 1.52$

1.49

1.45

1.4

1.4
C. Central and southern intermediate shelf $\mathrm{D}$ vs shelf edge A. Average dissimilarity $=86.3$

$\begin{array}{lccr}\text { Species } & \text { Av. Ab. D } & \text { Av. Ab. A } & \text { R } \\ \text { Arnoglossus laterna } & & & \\ \text { Merlucciusmerluccius } & 87.95 & 0 & * 4.57 \\ \text { Gobiusniger } & 815.42 & 10.38 & 1.31 \\ \text { Engraulisencrasicolus } & 11.35 & 0 & * 1.75 \\ \text { Trachurus spp. } & 25.19 & 0 & * 2.05 \\ \text { Arnoglossus thori } & 0 & 12.89 & * 1.62 \\ \text { Citharus linguatula } & 27.77 & 0 & 1.24 \\ \text { Lepidorhombus boscii } & 83.7 & 0.13 & 0.78 \\ \text { Spicara maena } & 46.86 & 0.38 & 1.14 \\ \text { Lophiuspiscatorius } & 0.12 & 4.53 & * 2.83\end{array}$

D. Northern intermediate shelf $\mathrm{C}$ vs upper slope B.

Average dissimilarity $=84.81$

Species

Av.ab. C Av. ab. B

$\mathrm{R}$

Micromesistius poutassou
Gadiculus argenteus
Arnoglossus laterna
Trachinus draco
Phycis blennoides
Helicolenus dactylopterus
Merluccius merluccius
Lepidopus caudatus
Mullus surmuletus
Citharus linguatula

$\begin{array}{lcc}0 & 179.22 & * 2.15 \\ 0 & 87.78 & * 1.73 \\ 56.56 & 1.77 & 1.43 \\ 9.04 & 0 & * 3.47 \\ 0 & 21.88 & * 1.63 \\ 0.12 & 79.84 & 1.39 \\ 19.86 & 128.02 & * 1.64 \\ 2.22 & 137.88 & 1.15 \\ 6.53 & 0.81 & 2 \\ 8.62 & 3.29 & * 1.63\end{array}$

E. Central and southern intermediate shelf D vs upper slope B. Average dissimilarity $=85.83$

Species
Arnoglossus laterna
Merluccius merluccius
Micromesistius poutassou
Gobius niger
Gadiculus argenteus
Cepola rubescens
Engraulis encrasicolus
Lepidorhombus boscii
Trachurus spp.
Phycis blennoides

Av. ab. D
87.95
815.42
0.19
34.35
0
17.02
118.55
83.7
25.19
0

Av. ab. B

$\mathrm{R}$

Phycis blennoides

$\begin{array}{rr}1.77 & * 2.49 \\ 128.02 & 1.26 \\ 179.22 & * 1.99 \\ 0.03 & * 1.65 \\ 87.78 & * 1.68 \\ 1.04 & * 2.25 \\ 0 & 1.12 \\ 12.04 & 1.22 \\ 0.03 & * 1.86 \\ 21.88 & * 1.61\end{array}$

B. Northern intermediate shelf $\mathrm{G}$ vs shelf edge A. Average dissimilarity $=77.52$

Species
Arnoglossus laterna
Trachinus draco
Lophius piscatorius
Citharus linguatula
Mullus surmuletus
Arnoglossus thori
Aspitrigla cuculus
Merluccius merluccius
Deltentosteus quadrimaculatus
Serranus hepatus

Av.ab. C Av.ab. A

$\begin{array}{ll}56.56 & 0 \\ 9.04 & 0 \\ 0 & 4.53 \\ 8.62 & 0 \\ 6.53 & 0 \\ 5.31 & 12.89 \\ 16.01 & 0.25 \\ 19.86 & 10.38 \\ 7.64 & 0.63 \\ 9.02 & 2\end{array}$

Serranus hepatus

F. Central and southern intermediate shelf $\mathrm{D}$ vs northern intermediate shelf C. Average dissimilarity $=69.94$

$\mathrm{R}$

$* 1.69$

$* 5.44$

$* 3.74$

$* 2.22$

$* 3.38$

1.34

1.13

1.2

1.33
Species

Merluccius merluccius

Gobius niger

Engraulis encrasicolus

Arnoglossus laterna

Cepola rubescens

Lepidorhombus boscii

Spicara maena

Trachurus spp.

Citharus linguatula

Aspitrigla cuculus

Av. ab. D

815.42
34.35
118.55
87.95
17.02
83.7
46.86
25.19
27.77
0.06

1.41
$\mathrm{R}$

1.25

$* 1.74$

1.14

$* 1.5$

*2.03

0.82

1.15

*1.6

1.49

1.06 


$\begin{array}{lccr}\text { Species } & \text { Av. ab. E } & \text { Av. ab. B } & \text { R } \\ \text { Sardina pilchardus } & 1550.22 & 0 & 1.26 \\ \text { Engraulis encrasicolus } & 546.96 & 0 & * 1.57 \\ \text { Arnoglossus laterna } & 114.77 & 1.77 & * 2.77 \\ \text { Mullus barbatus } & 125.59 & 0.03 & 1.36 \\ \text { Micromesistius poutassou } & 0.3 & 179.22 & * 1.92 \\ \text { Lesueurigobius friesii } & 116.69 & 0 & 1.41 \\ \text { Deltentosteus quadrimaculatus } & 58.74 & 0 & * 1.95 \\ \text { Citharus linguatula } & 53.57 & 3.29 & * 1.85 \\ \text { Gadiculus argenteus } & 0 & 87.78 & * 1.63 \\ \text { Merluccius merluccius } & 29.31 & 128.02 & * 1.57\end{array}$

H. Shallow waters E vs northern intermediate shelf C. Average dissimilarity $=71.46$

$\begin{array}{lccc}\text { Species } & \text { Av. ab. E } & \text { Av. ab. G } & \text { R } \\ & & & \\ \text { Sardina pilchardus } & 1550.22 & 0 & 1.29 \\ \text { Engraulis encrasicolus } & 546.96 & 0 & * 1.63 \\ \text { Lesueurigobius friesii } & 116.69 & 0 & 1.48 \\ \text { Mullus barbatus } & 125.59 & 8.38 & * 1.53 \\ \text { Arnoglossus laterna } & 114.77 & 56.56 & * 1.6 \\ \text { Gobius niger } & 23.94 & 0.52 & 1.43 \\ \text { Deltentosteus quadrimaculatus } & 58.74 & 7.64 & 1.27 \\ \text { Pagellus acarne } & 67.3 & 0.62 & 1 \\ \text { Merluccius merluccius } & 29.31 & 19.86 & 1.35 \\ \text { Trachinus draco } & 3.95 & 9.04 & * 2.04\end{array}$

Appendix 1. (Continued).

G. Shallow waters E vs Upper slope B.

Average dissimilarity $=92.79$

I. Shallow waters E vs shelf edge A.

Average dissimilarity $=90.37$
Species

Sardina pilchardus

Engraulis encrasicolus

Arnoglossus laterna

Mullus barbatus

Lesueurigobius friesii

Citharus linguatula

Deltentosteus quadrimaculatus

Gobius niger

Arnoglossus thori

Lophius piscatorius
Av. ab. E Av. ab. A

$\mathrm{R}$
Merluccius merluccius
$* 1.57$

J. Shallow waters E vs central and southern intermediate shelf D. Average dissimilarity $=62.9$

Species

Sardina pilchardus

Merluccius merluccius

Engraulis encrasicolus

Lesueurigobius friesii

Mullus barbatus

Deltentosteus quadrimaculatus

Cepola rubescens

1550.22

546.96

114.77

125.59

116.69

53.57

58.74

23.94

0

0
1.32

$* 1.66$

$* 6.1$

$0.13 \quad 1.45$

$0 \quad 1.46$

$0 \quad * 2.71$

$0.63 * 1.83$

$0 \quad 1.42$

$12.89 * 1.55$

$4.53 * 3.11$

$\begin{array}{llll}\text { Pagellus acarne } & 67.3 & 6.64 & 1.27\end{array}$

$\begin{array}{llll}\text { Spicara maena } & 7.05 & 46.86 & 1.09\end{array}$

$\begin{array}{llll}\text { Lepidorhombus boscii } & 0.22 & 83.7 & 0.73\end{array}$ 